\title{
Participation of Project Beneficiaries in Planning and Implementation of Poverty Reduction Policies and Projects in Baringo North Sub-County: Gendered Perspective
}

\author{
Lilian R. Chesikaw \\ Institute of Women, Gender and Development Studies, Egerton University, Njoro, Kenya
}

Email address:

lchesikaw@yahoo.com

To cite this article:

Lilian R. Chesikaw. Participation of Project Beneficiaries in Planning and Implementation of Poverty Reduction Policies and Projects in Baringo North Sub-County: Gendered Perspective. Advances in Sciences and Humanities. Vol. 2, No. 5, 2016, pp. 48-55.

doi: 10.11648/j.ash.20160205.12

Received: August 27, 2016; Accepted: November 2, 2016; Published: December 12, 2016

\begin{abstract}
In most low and middle income countries, poverty has been a critical challenge. This has been more real especially in Nations where social problems like gender imbalance, marginalization, tribalism and corruption are rampant. In such Nations, women and children have become more vulnerable than the male counterparts. Numerous efforts have been initiated by different stakeholders including governments and non-governmental organizations. These efforts include formulation of poverty reduction policies and implementation of community based poverty reduction projects. Studies have suggested that inclusivity and community involvement is important if such projects are to succeed. This study sought to examine participation of project beneficiaries in the planning and implementation of poverty reduction policies and projects in Baringo North Sub- County, from a gendered perspective. The study collected data from community members including; church leaders, government officials, officials from non-governmental organizations and members of the community. The study revealed that both men and women were involved in fundraising and resource mobilizations and sometimes they were engaged in projects activities. Similarly, majority of the beneficiaries participated as project members, others as the leaders of those projects, some as community representatives while the least played the role of being contact persons while a significant number did not have a single role to play in those projects, majority of who were women. More so, it is worth noting that in all the participation, women formed the least number from idea formulation to implementation. Participation by the project beneficiaries in the planning and implementation of the projects significantly differed on the basis of the gender of the respondents. This therefore implies that gender variable determined allocation of opportunities and responsibilities in the projects. The study recommends that community members should be actively involved in the entire project cycle in order to eliminate the feelings of discrimination on the impacts of the projects. It is also suggested that all community members should be involved at all levels in the project cycle even if it is attending meetings so that they can know what is happening and air their views. That will go a long way in promoting a sense of ownership and to ensure success and sustainability. It will also promote transparency and accountability which help in the proper use of resources and benefit.
\end{abstract}

Keywords: Inventory Control, Inventory Control Strategies, Inventory Record Accuracy

\section{Introduction}

The major goals of development projects are to empower communities by reducing their state of powerlessness in which people are denied their rights and the ability to control their lives. However, the situation in Baringo North Sub-County showed little or no impact of those projects on the lives of the people, especially the women. This therefore necessitated the evaluation of implementation approaches of development projects in order to ascertain their benefits to communities from a gendered perspective.

The vulnerability of women to poverty arises from various factors, ranging from harmful cultural practices to lack of access to resources which normally have huge negative impacts on their lives. In Baringo, the culture practiced by the community is such that women do not inherit property ad have 
little or no voice on resource allocation and control. Many are excluded during project implementation and many times are used as rubber stamps to access funds different quarters. That makes them more vulnerable since they can neither decide nor own property, yet the care of the family is solely their responsibility.

A study done by the International Food Policy Research Institute (IFPRI) similarly established that in general there were more women than men in poor households in half of the data sets from Africa, and that in eight of IFRI 15 data sets covering 14 countries, there were more than 110 women in households in the poorest expenditure/income quintile (IFRI, 2002). In Kenya more than $56.3 \%$ of the populations live below the poverty line, of which majority of these are women, according to (Gender \& Millennium Development Goals Report, 2005) and. Similarly, the percentage of the people living below the poverty line in Baringo North district is $46 \%$, ranking according to the 2009 household survey (National Agency for Population, 2009). The sad reality is that as much as women and girls bear the brunt of poverty, its consequences will affect everyone's wellbeing in the long run and hinder development (World Bank Policy Research Report, 2002).

Non-Governmental Organizations (NGOs) and Faith Based Organizations (FBOs) too have done a lot in trying to reduce poverty by initiating various development projects. Some of the development projects include construction of schools, hospitals, provisions of scholarships for needy children, small business startups and nutritional skills among others. Many people in those areas benefited immensely through accessing drugs in hospitals and better health services. That helped to lower child and maternal deaths and improved nutritional health.

The reality on the ground was that the women were neither participating fully nor benefiting from the proceeds accrued from those projects. This goes against Chambers (1998) who proposes that the reality of the poor matters and they must be included at all levels of project formulation, implementation and evaluation. Marginalization of the poor segments of society, majority of whom are women, means that their voice has been left out. This pushes them further into poverty.

\subsection{Research Objective}

To examine the level and nature participation of project beneficiaries in the planning and implementation of poverty reduction policies and projects in Baringo North Sub-County, from a gendered perspective

\subsection{Research Hypothesis}

HO: There are no statistically significant level and nature of participation by the project beneficiaries in the planning and implementation of the policies and projects in Baringo North Sub-County on the basis of their gender.

\section{Literature Review}

\subsection{Poverty Reduction Policies and Projects in Kenya}

Though Kenya has experienced impressive growth in many areas of development, figures in the last five years, show that ordinary Kenyans are still wondering how to escape the poverty trap, UNDP (1993) asserts that new politics on poverty prioritizes economic growth and government stability over the real interests of poor people. It is however worth noting that Kenya started the struggle of reducing poverty some years back and some of its efforts have undergone a lot of changes to inform its current inputs towards poverty reduction.

Some of the recent efforts by the Kenyan government to reduce poverty include: availing cheap loans for women and youth. The national youth service programme that has greatly helped to change the lives of the jobless youths who are using their time in profitable activity and earning income, drilling boreholes in various parts of the country to ensure that Kenyans access water for their use and many irrigation projects have come up based on that input, road infrastructure development: enhancing access to education, provision of free medical treatment, encouraging sustainable agriculture and increasing funds constituency development fund to encourage development at constituency level.

\subsection{Beneficaries Participation in Poverty Reduction Projects}

The World Bank has identified the reduction of extreme poverty facing marginalized and vulnerable groups as among its key priorities and it has targeted local communities with social funds (Plant, 1998). According to Muteshi (2006), unless projects on poverty reduction are accorded enough budgetary package and the conditions within them friendly to poor women, poverty reduction and meaningful development may not be realized any time soon. This could be true also in relation to policies of the government when dealing with poverty alleviation, especially in marginalized rural areas like Baringo North and specifically the lower Asal ASAL areas where pastoralism is a major source of livelihood. The presence of the government there and its activities are limited and the people are languishing in poverty. Ironically, huge amount of resources are allocated to poverty alleviation in the national budget yet its impacts are not felt by the poor especially the women.

Baringo County is inherently patriarchal like many Kenyan communities and so the women's participation in development projects is minimal even if the projects are targeted to benefit them. Women suffer gender inequality, end up becoming vulnerable and bearers of the brunt of poverty with their children. They are victims of social relations that undermine them, limit their participation, voice and their needs. In Baringo for example, women have little or no education, many die when giving birth due to lack of basic health facilities, suffer from hunger and insecurity among others.

The results of the projects pointed out to the limits of poverty-targeting mechanisms and to the need for special efforts to achieve greater participation by the local people especially women who are always not included in the projects, deterring them from making their demands known. More so, it should be noted that since the mapping of gender disparities in 
poverty and their resolution is well suited to participatory methods, the quality and the sensitivity of the processes are crucial.

The GOK and NGOs involved in projects to alleviate poverty need to be sensitive to the prevailing strengths and challenges within their set of approaches. Goals aimed at equipping people with tools to help them make informed choices to improve their wellbeing must be effective. Identification of those needed to carry out empowerment activities must also be people who are known and trusted by the society if those goals are to be achieved. They will be able to identify the right people to be empowered through the projects and who will cause positive impact. This is because as Chambers (1992) cautions, thwhether empowerment is good depends on who is empowered and how their new power is used. He claims that the tendency of a participatory method has always been about men rather than women.

Research has shown that normally this method targets man and its effects are adverse on women. Chambers (1992) further asserts that projects should aim at alleviating poverty, providing employment and improving the health status of community members and if these three areas are not addressed, then the projects may not bear much relevance to the community.

Poverty Reduction activities and projects in Baringo County have been some of the key approaches in changing people's vulnerable situations and bettering lives. North Baringo Sub-County too has many such projects aimed at reducing poverty and this research will be able to unpack the impacts of such projects. The study identified project challenges in the Sub County and provided appropriate recommendation. This literature brings to fore the insights of poverty reduction efforts and provide best practices to the quest of improving peoples' lives.

\section{Research Methodology}

This study used a case research design. Baringo North Sub-County was used as a case. The study employed both quantitative and qualitative methods to collect information about participation in poverty reduction policies and projects (Orodho \& Kombo, 2002). According to Njeru (2004), qualitative methods enable the researcher to gain empathetic understanding of social phenomena. Since the research topic required more exploration in order to provide a more detailed view of the issues (Creswell, 2003), the study used both qualitative and quantitative research methods.

The study's target population was made up of 2400 households of Baringo North sub-county. The subjects of investigation were household heads within the project areas, community stakeholders, women and district development officers and the officials involved in the projects. According to Kerlinger (1983), ten percept of population in social science is allowed as a sample. The study employed random sampling to select as the sample size of study. This means 180 households for the two divisions were used for the study.

The study used both self-administered schedules and questionnaires to collect data. The questionnaires contained both structured and unstructured questions for the sake of obtaining quality information. The instruments were developed in consideration of the study objectives. The collected data was coded with regard to the type and source. It was analysed and interpreted quantitatively and qualitatively.

\section{Findings, Conclusions and Recommendations}

\subsection{Findings}

\subsubsection{Beneficiary Participation in Project Planning}

Table 1. Beneficiary participation in project planning.

\begin{tabular}{lll}
\hline Involved in Project Planning & Frequency & Percent \\
\hline Yes & 6 & 100 \\
No & 0 & 0 \\
Total & 6 & 100 \\
\hline
\end{tabular}

It is clear from table 1 that all the respondents representing the sponsor or government and donor agreed to have consulted with or involved the target groups before starting any project intervention in the study area. It is worth noting that stakeholder participation is a critical factor in determining the continuity of the project and its eventual sustainability. This is because it is quite difficult to know the mind of the project formulator unless he/she is there from the hatching of the project to its completion. This is the very reason why target groups were consulted from the beginning so that right from the onset they would have an idea of the overall goal of the project and how it would be implemented and sustained. However, it was found that their involvement mostly was to attend meetings where they were told about the new projects, what would happen and not what they thought about the projects. Therefore they did not have their way in designing the projects, especially the women.

\subsubsection{Beneficiary Participation in Project Initiation}

Table 2. Beneficiary participation in project initiation.

\begin{tabular}{llll}
\hline & Group involved & Frequency & Percent \\
\hline \multirow{2}{*}{ Formulation of } & Community & 6 & 100 \\
objectives & Sponsor & 0 & $0 \%$ \\
& Total & 6 & 100 \\
\hline
\end{tabular}

From table 2, it can be observed that $100 \%$ of the respondents, who represented the sponsor, indicated that the community was totally involved in every aspect of the projects that were being implemented. The table further reveals that the involvement of the community was on objectives formulation. This implies that the communities were very much involved at the objective formulation stage which is a critical factor in participatory community development. In view of this, it can be observed since the community was fully involved in the formulation of the objectives of the project all the issues affecting the community were adequately covered. It can therefore be concluded that the objectives were relevant to the 
needs of the society. This view concurs with that of Starling (1979) who posits that in every policy design, community involvement is critical since the issues on the ground are likely to be addressed through generating relevant objectives.

\subsubsection{Level of Consultations with Target Beneficiary}

Table 3. Extent of stakeholder consultation.

\begin{tabular}{lll}
\hline Stakeholders & Frequency & Percent \\
\hline Church & 12 & 6.9 \\
Community & 64 & 37.0 \\
Community Leaders & 65 & 37.6 \\
Men & 4 & 2.3 \\
Women & 9 & 5.2 \\
Youth & 12 & 6.9 \\
None-No one Consulted & 1 & 0.6 \\
Others e.g Governor, MP, GoK & 6 & 3.5 \\
Totalt & 173 & 100.0 \\
\hline
\end{tabular}

It can be observed from table 3 that majority of the stakeholders who were consulted were the community leaders $(37.6 \%)$ followed closely by the community $(37.0 \%)$. Others who included the church were consulted about 7 times in 100 occurrences while the youth were also consulted 7 times in 100 occurrences. It is also observed that consultations with the women were about $5 \%$ while that with men only was less than $3 \%$. It is worth noting that elected leaders were consulted in three occasions out of a possibility of 100 occasions. From these findings it is evident that majority of the respondents (99\%) were consulted during project planning phase save for only $0.6 \%$ of the respondents who corresponded with the percentage number of illiterates in the study area as Stakeholder Participation in Project Initiation in the table 3.

A critical observation of the findings in table 3 further indicates that $74.6 \%$ of the respondents who were consulted were the community and community leaders. This implies that majority of the projects implemented in the study area were generally tailored to improve the lives of the people in the community in general and not for a particular section of the community. However, it could be seen that there were projects tailored to address the needs of specific groups such as the church, youth, and women which required them to be consulted. It is worth also to note however, that men were consulted the least implying that projects mainly tailored to address the needs of men only were negligible.

That could imply that men may not have serious poverty challenges since they own and control resources in society hence their problems may not be as many as the ones for women and youth who do not enjoy such opportunities. It could also mean that men are already aware and even participating in many of the projects in the area. This also may have been due to the general belief that in most communities in the African context, women are more vulnerable compared to the men and in most cases the former are well-versed with the challenges that affect the community.

According to African culture, men have voice, so they make decisions for women, youth and children and also inherit property. In fact in most cases they are the ones who would run and manage the projects even if they were meant for women or children. Largely, women, children and youth are dependent on men and that marginalizes them even more into poverty. In light of this therefore it would be obvious that consultation with men was not necessary since they were not considered to be within the vulnerable bracket. Another most likely reason is that the people of Baringo like any other Patriarchal African Society, do not delineate people along gender lines and even when the projects are put in place they would not treat them literally as gender issues being addressed.

Another observation from the respondents was that when a baraza (public meeting) was called, normally there was prior information about the objective of the meeting and so if it was about helping women and youth, then they were likely to attend since they would benefit from what would be discussed. Indeed, most community projects targeted various sections of the community which are considered marginalized such as women, youth, and people with disability, (GoK, 2013).

This is premised on the perception that these groups are victims of poverty and needed help. The pertinent issue here therefore is that their issues are solved through programmes and projects and they are not a mainstream consideration in policy making. It calls for critical reasoning and questions on what would happen to the women and youth if those programmes and projects do not come by since most projects are temporary by nature and so sustainability of benefits would not be guaranteed. This point contributes and explains their high participation in the meetings, since each one of them hopes to stand a better chance to access and enjoy the benefits of the projects by being considered through their attendance.

\subsubsection{Participation of Beneficiaries at Various Levels of Project Cycle}

Table 4. Participation of beneficiaries at various levels of project cycle.

\begin{tabular}{lll}
\hline & Frequency & Percentage \\
\hline Attending meetings & 2 & 33 \\
Helping in resource mobilization & 3 & 50 \\
Working on projects & 3 & 50 \\
Teaming up with NGOs & 1 & 17 \\
Committee members & 1 & 17 \\
Idea generation & 2 & 33 \\
\hline
\end{tabular}

It can be observed that nearly $17 \%$ of the participants agreed that the target group members were assisting in resource mobilization and directly working in the project areas. A total of $33 \%$ of the respondents were involved in idea generation and attending meetings while $17 \%$ of the respondents were committee members. Overall, the findings seem to be in support of those from the household survey which found that there was stakeholder participation in the project with various participants taking various roles during project implementation. These findings concur with those of Mitulla (2005) who in his study on stakeholder involvement in project design and implementation established that stakeholders had directly been involved in working with projects and mobilizing resources especially personnel necessary for the success of the projects.

However, many perspectives can be understood from the 
above findings. Firstly, the numbers of the stakeholders involved at the various levels within the project cycle were low compared to the study population. That could mean that many of them were not aware of the projects or did not know their importance to them. From the discussions, the resource mobilization referred to here was in the name of Harambees (coming together in unity to collect funds) through which people mobilized themselves and collected funds and other resources to run the projects especially the community ones. Working on the projects meant that since they were their own projects, they were more willing to be involved in them. In fact the community projects which were initiated by them performed better than other projects in the area.

However, during the FGD sessions the members said that in some of the projects especially those sponsored by the government, government officers, the chiefs, chairmen of some committees or chairladies of some village women's' organizations were responsible for the disbursement of funds to the various target groups. It was said that some of those who controlled the government funds were corrupt and diverted some of the funds to other uses and some even used them for their own personal gain. That explains why funds did not complete the projects and some of them stalled.

Within the NGOs projects also, the target groups organized themselves and they were given opportunity to have a say through their own group leaders on what should happen including how the funds were to be shared. They made decisions on the best way they wanted to run the projects. The project employees served as facilitators and supervisors to ensure that the objectives were achieved

A Similar analysis of interview schedule from sponsor on the same dimension corroborated the fact that all the stakeholders were actively involved in the various cycles of the project in various capacities as shown in table 5 .

\subsubsection{Nature of Beneficiaries Participation in Projects}

Table 5. Ways the beneficiaries are involved in projects.

\begin{tabular}{lll}
\hline Participation ways & Frequency & Percent \\
\hline Decision making & 6 & 46 \\
Working on project area & 2 & 15 \\
Attending meetings & 2 & 15 \\
Managing project & 3 & 24 \\
Total & 13 & 100 \\
\hline
\end{tabular}

As can be noticed from table 5, the various capacities in which the target beneficiaries were engaged in the projects included: decision making (46\%), managing the project (24\%), attending meetings (15\%), and working in the project area $(15 \%)$. As shown earlier in table 6 , the above figures reflected what happened in community projects and in those sponsored by other bodies other than government. In the projects that were initiated by the community members, they were the ones who made decisions on how they should be run.

Also within the NGO projects, the target groups were given opportunity to air their views. That went a long way in inculcating a sense of ownership which promoted sustainability within the project cycle period in many of those projects. That also explained the reason why NGOs' lasted longer than those of government and were better felt. The only problem of those projects was their sustainability after their cycles were completed and it is important that a high level of stakeholder engagement in the projects is a recipe for project sustainability.

\subsubsection{Gender Disaggregation in Project Participation}

Table 6. Gender disaggregation in project participation.

\begin{tabular}{|c|c|c|c|c|c|c|}
\hline \multirow{2}{*}{ Gender of respondent } & \multicolumn{5}{|c|}{ Number of projects the Respondent participate in } & \multirow{2}{*}{ Total } \\
\hline & 1 & 2 & 3 & 4 & None & \\
\hline Female & $22(13 \%)$ & $17(10 \%)$ & $4(2.3 \%)$ & $23(13.3 \%)$ & $9(5.2 \%)$ & $75(43.8 \%)$ \\
\hline Male & $36(20.8 \%)$ & $35(20.2 \%)$ & $7(4.0 \%)$ & $15(8.5 \%)$ & $5(2.8 \%)$ & $98(56.2 \%)$ \\
\hline Total & $58(33.8 \%)$ & $42(24.3 \%)$ & $11(6.3 \%)$ & $38(22.0 \%)$ & $14(8 \%)$ & $173(100 \%)$ \\
\hline
\end{tabular}

It can be observed from table 6 that majority of the men participated in either one $(20.8 \%)$ or two $(20.2 \%)$ of the projects compared to $13 \%$ and $10 \%$ of the females respectively. Interestingly though, majority of the women participated in four projects $(13.3 \%)$ as compared to their male counterparts at $8.5 \%$ which signifies the ability of the women to multitask. In spite of this however, the level of participation in the projects by women was significantly low percentage wise at $38.6 \%$ compared to that of males at $56.2 \%$ which is one -half times that of the females. Many reasons can be explained for these findings; many women may have been aware of the projects but may not have comprehended on the importance of participating in those projects as compared to men. According to the culture practiced in that area; women were expected to be pre-occupied with household responsibilities and would not have enough time for project participation and so important information many times rests in men who participate in public meetings. In fact many women rely on their spouses to explain the importance and benefits of those projects for them to make important choice to participate, since they believe that men know a lot of things and so their guidance and advice is beneficial to them.

High illiteracy levels among the women could also have contributed to the women's less numbers in project participation. They might not have comprehended the value that the projects would add to their livelihoods. Lack of education could also have had contributed to poor self-esteem from which could have made the women shy away from project participation. This meant that their voice was locked out hence their issues were not considered.

Another perspective to poor women's participation could be alluded to the culture of the community which does not give opportunity to women to make decisions especially about duties and responsibilities and so the men would not allow them to participate in public projects since it was believed that it would compromise their family responsibilities. They were 
not allowed to address men in public forums or become leaders and this could have hindered some of them from participating in the projects since they knew their views may not be considered. One of them retorted, "What is the use of participating in processes that one is not allowed to air her views?" a respondent complained.

From the findings, one can conclude that man more than women have better awareness levels of the projects, a fact which was reflected in their numbers in project participation. The small percentage $(2.8 \%)$ of men who did not participate in any project compared to women's $(5.2 \%)$ meant that majority men took part in projects than women. The percentages of men diminished as the number of projects diminished which could mean that either men had information about the benefits of the projects and concentrated in more profitable projects, leaving the none- profitable ones or they cannot handle too many things at the same time. Women continued to spread to various projects, showing their capacity to handle many things.

\subsubsection{Hypothesis Testing}

The study sought to establish whether there were differences nature and level of participation by the project beneficiaries in the planning and implementation of the development projects in Baringo North Sub-County from a gendered perspective. In order to achieve this objective, the second null hypothesis was formulated thus: H0: There is no statistically significant gender differences in nature and level of participation by the project beneficiaries in the planning and implementation of the development projects in Baringo North Sub-County. In order to establish the truth of this hypothesis, a chi- square test was run at the. 05 level of significance. The results of this finding are presented in table 7 .

Table 7. Participation of beneficiaries on basis of gender

\begin{tabular}{llll}
\hline & Value & Df & Asymp. Sig. (2-sided) \\
\hline Pearson Chi-Square & $24.368 \mathrm{a}$ & 5 & .000 \\
Likelihood Ratio & 26.718 & 5 & .000 \\
Linear-by-Linear Association & 17.889 & 1 & .000 \\
N of Valid Cases & 173 & & \\
\hline
\end{tabular}

From the chi-square statistics in table 7 , it is noted that the percentage participation by the project beneficiaries in the planning and implementation of the development projects did significantly differ on the basis of the gender of the respondents, $\chi^{2}(5, \mathrm{~N}=173)=24.368, \mathrm{p}=.000$. This implies that the variable gender and the role played by project beneficiaries in planning and implementation of development projects were not statistically related $(\mathrm{p}<.05)$. This implies that both men and women had a significant role to play in any phase of project development a distinct discrimination on the basis of gender. This shows that the relationship between gender and participation in the project had a statistically significant relationship and hence the null hypothesis was rejected. Any disparity as noticed from table 7 can be attributed to chance error.

\subsection{Conclusions}

The study concluded that most of the time, both men and women participate in fundraising and resource mobilizations and sometimes they were engaged in team activities. Similarly, majority of the beneficiaries participated as project members, others as the leaders of those projects, some as community representatives while the least played the role of being contact persons while a significant number did not have a single role to play in those projects, majority of who were women. More so, it is worth noting that in all the roles, women formed the least number from idea formulation to implementation. The roles played by the project beneficiaries in the planning and implementation of the projects significantly differed on the basis of the gender of the respondents. This therefore implies that the gender variable determined allocation of opportunities and responsibilities in the projects.

\subsection{Recommendation}

It is important for community members should be actively involved in the entire project cycle in order to eliminate the feelings of discrimination on the impacts of the projects. Many of the people that said that they were left out in the project activities complained that they did not benefit from them. They had a feeling that the projects belonged to other people and did not see how they would support them. That contributed to some of the project failures that were seen in the study area. It is suggested that all community members should be involved at all levels in the project cycle even if it is attending meetings so that they can know what is happening and air their views. That will go a long way in promoting a sense of ownership and to ensure success and sustainability. It will also promote transparency and accountability which help in the proper use of resources and benefit.

\section{References}

[1] AgriFin (2013). Trade Finance: Warehouse and Inventory Management in Africa. Retrieved March 28, 2016, from AgriFin:http://agrifinfacility.org/trade-finance-warehouse-andinventory-management-africa

[2] Aliber, M. (2001). Chronic poverty and development policy. Cape Town: University of Western Cape.

[3] Anderson, M. (1999). The poor are not us; poverty and pastoralism. Nairobi: East African Educational Publishing.

[4] Ayako, B. A \& Katumanga M. (1997). Review of property in Kenya. Nairobi: Institute of Policy Analysis and Research.

[5] Baringo District Data Profile. (2006). District Development Department. Kabarnet.

[6] Barker, D. and Edith K. (2006). Feminist economics and the World Bank, history, theory and policy. London: Routledge.

[7] Beall, J. and Clert, C. (2000) Social exclusion and Globalization; Implications for Social Policy and Urban Governance. London: Department of social Policy, London School of Economics, World Bank.

[8] Best, J. W. \& Khan, J. V. (1998). Research in Education (5 $5^{\text {th }}$ ed.). New Delhi: Prentice Hall. 
[9] Black, T. R. (1995). Evaluating Social Science Research: An Introduction. London: Sage.

[10] Bogdan, R. C. \& Biklen, S. K. (1992). Qualitative Research for Education: An introduction to Theory and Methods. Boston: Allyn \& Bacon.

[11] Burkey, S. (1993). People First; A Guide to Self Reliant Participatory Rural Development. London: Zed Books Ltd,

[12] Bryman, A. (2004). Social Research Methods. New York: Oxford University.

[13] Buzan, Tony. (1995) The Mind Map Book: Radiant Thinking London: BBC Books.

[14] CARE (2002). Defining characteristics of rights based approach, promoting rights and responsibilities. Atlanta USA.

[15] Catagay, N, Elson, D. and Grown, C. (2000) Growth trade Finance and Gender Inequality World Development.

[16] Chambers. R. (1995) "Poverty and Livelihoods: Whose reality Counts?" IDS discussion paper No.347. UK.

[17] Chambers, R. (1992). Rural Appraisal: Rapid, Relaxed and Participatory; Discussion Paper NO.311, Success: IDS, UK.

[18] Chambers, R. (1991). Rural Development; Putting the Last First. New York. Longman Scientific \& Technical.

[19] Chambers, R. (1989). Vulnerability: How the Poor Cope. IDS Bulletin, Uk.

[20] Cohen, L. \& Manion, L. (2000). Research Methods in Education ( $2^{\text {nd }}$ ed.). London: Croon Helm.

[21] Colclough, C. Rose, P and Tembon, M. (2000). Gender inequalities in Primary Schooling: the roles of poverty and adverse cultural practice. International Journal of Education Development.

[22] COMESA (2002). Gender Policy. Lusaka, Zambia Convention on the Elimination of all forms of discrimination against women in Kenya. Faculty of Law, University of Nairobi.

[23] Creswell, J. W. (2003). Qualitative, Quantitative and Mixed Methods Approaches ( $2^{\text {nd }}$ ed.). Thousand Oaks, CA: Sage.

[24] Eade, D. (2010). Development in Practice; Stimulating Thought for Action, New York: Routledge.

[25] Edith, K. and Barker, D. (2006). Feminist Economics and The World Bank, History, Theory and Policy. New York: Routlegde.

[26] Emma, T. L. (2003). Food Insecurity and Coping Strategies in semi-Arid Areas. Sweden: Stockholm University.

[27] Eversole, R. (2005). Indigenous Peoples \&poverty and International Perspectives. London and New York: Zed Books.

[28] Flavell, J. H. (1963). The Developmental Psychology of Jean Piaget. New York: Van Nostrand Reinhold.

[29] Flick, U. (2002). An Introduction to Qualitative Research (2 ${ }^{\text {nd }}$ ed.). London: Sage Publications.

[30] Foeken, D. (2008) In side Poverty and Development in Africa, critical reflection on pro- poor policies. Brill, Lei Nairobi den, Netherlands.

[31] Fowler, F. J. Jr. (1993). Survey Research Methods (2nd ed.) Newbury Park, CA: Sage.
[32] Fraenkel, J. R. \& Wallen E. N. (2000). How to Design and Evaluate Research in Education. ( ${ }^{\text {th }}$ Ed. Boston: McGraw Hill

[33] Goetz. A, M (1997). Getting Institutions Rights for Women in Development. London and New York: Zed books.

[34] Goetz, A. M (1995). Macro-Meso-Micro Linkages; Understanding Gendered Institutional Structures and Practices; Ottawa, USA.

[35] GOK (2010). Constitution of Kenya, Laws of Kenya 2010, Nairobi; National Council of Law Reporting

[36] GoK (2003). Millennium Development Goals; A Progress Report for Kenya. Nairobi: Government Printer.

[37] GoK (2007). Kenya Vision 2030. Nairobi: Government Printers.

[38] GOK (1999). National Poverty Eradication plan 1999-2015: Office of the president, Department of the Development Coordination. Nairobi: Government printers.

[39] Gready, P. and Ensor, J. (2005). Reinventing Development; Translating Rights-Based Approaches from Theory into Practice. New York: Zed books.

[40] Gutierrez, (2003). Macro Economics making Gender matter; Concepts, Policies, institutional Change in Developing countries. London and New York: Zed books.

[41] Hodgson, D. L. (1995). The Politics of Gender, Ethnicity, and Development; Images Intervention and Reconfiguration of Maasai Identities. New York: University of Michigan.

[42] Hughes, (2002). The World Bank Source book for Poverty Reduction Strategies. Washington: World Bank.

[43] Illife, J. (1987). The African poor; A History. Cambridge: Cambridge University Press.

[44] Jonson, U. (2003). Human Rights Approach to Development Programming. Nairobi: UNICEF Kenya.

[45] Kabeer, N. (2003). Gender Mainstreaming in Poverty Eradication and the Millennium Development Goals; A handbook for policy-makers and other stakeholders. Commonwealth Secretariat, United Kingdom

[46] Kabeer, K. (1994). Reversed Realities: Gender Hierarchies in Development Thought. London: Commonwealth Secretariat, United Kingdom.

[47] Kathuri, J. K. \& Pals, A. D. (1993). Introduction to Educational Research. Njoro, Educational Material Centre, Egerton University.

[48] Kerre F. (1994). The Impact of the SAPs on Kenyan Women Small Scale Enterprises: The case of Nairobi and Eldoret, Unpublished Paper.

[49] Kerlinger, F. N. (1983). Foundations of Behavioral Research. New York: Holt, Renehart and Winston.

[50] Kolawole, May E. M. (2004). Re-conceptualizing African Gender Theory: Feminism, Womanism, and the Arere Metaphor. In Arnfred, S. (Ed) Re thinking Sexualities in Africa. Uppsala: The Nordic Africa Institute.

[51] Kolawale, Mary E. M. (1997). Womanism and African Consciousness. Eritrea. Africa. 
[52] Kombo, K. D. \& Tromp, A. L. (2006). Proposal and Thesis Writing: An introduction Nairobi: Pauline's publication Africa.

[53] Kothari, C. R. (2007). Research Methodology, Methods and Techniques. New Delhi: New Age international (P) Ltd

[54] Kubasu, L. (2009). Baringo North Constituency Strategic Plan 2009-2019. Kabarnet. Nairobi: Government Printer.

[55] Martinez, C. A (1996). Study of the Problem of Discrimination Against Indigenous Populations; New York: United Nations.

[56] McNamara, C. (1999). General Guidelines for Conducting Interviews. Minnesota.

[57] Minh, Trinh T. (1989), Woman, Native, Other. Bloomington and Indianapolis: Indiana University Press.

[58] Ministry of Education. (2007). Gender Policy in Education. Nairobi: Government Printer.

[59] Ministry Gender, Sports, Culture and Social Services (2005). Guidelines for the Women the Enterprises Fund. Nairobi: Downtown Printing works Ltd.

[60] Momsen, J. (2004). Gender and Development. London. Routledge.

[61] Molyneux and Lasaar (2003). Doing the Right Thing. London: ITGD.

[62] Mugenda, O. M. \& Mugenda, A. G. (2003). Quantitative and Qualitative Research Methods. Nairobi Acts Press.

[63] Mujis, D. (2004). Doing quantitative Research in Education with SPSS. London;Sage Publications

[64] Mutheshi, J. (2006). Mapping Best Practices: Promoting gender equality and advancement of Kenyan women. Nairobi: Heinrich Boll Foundation.

[65] Nitko, A. J. (1996). Educational Assessment of Students. New Jersey. Messrill.

[66] Njeru, O, Gondi,(2005)Policy Based Approaches to Poverty Reduction in Kenya; strategies and civil society engagement, UNDP, Nairobi, Kenya.

[67] Nyamongo, I, (1998) Political Power and Gender equity: A Case Study of Nairobi and Nyeri Districts, Unpublished. Nairobi: Ministry of Planning and national development

[68] Omiti. J, Owino. W. and Odundo (2002). Poverty Reduction efforts in Kenya: Institutions, Capacity and Policy. Ipar discussion paper 033/2002, Nairobi, Kenya

[69] Orodho, A. J. and Kombo, D. K. (2002). Research Methods. Nairobi: Kenyatta University, Institute of Open Learning.

[70] Opie, K. (2004). Doing Educational Research, A Guide to First Time Researchers. London: Sage.

[71] Oxfam (2000) Towards Global equity; Strategic Plan 2001-2004. London: Oxfam international, UK.

[72] Palmer, I. (1991). Gender and Population in the Adjustment of African Economics: Planning for change. Geneva: International Labour Organization.

[73] Pilcher, J. (2006) 50 Key Concepts in Gender Studies. New Delhi. Sage Publications.

[74] Republic of Kenya (2010). The Constitution of Kenya. National Council for Reporting, Nairobi, Kenya.
[75] Republic of Kenya (2009) National Coordinating Agency for Population. Baringo District, Kabarnet. Nairobi: Government Printer.

[76] Rubin, H. J. \& Rubin, I. S. (1995). Qualitative Interviewing. The Art of Hearing Data. London: Sage.

[77] Saunders, (2000). Research Methods for Business Students. $5^{\text {th }}$ ed. Washington: Prentice Hall

[78] Segupta, A. (2003). The Human Rights to Development; Paper presented to Nobel Symposium Oslo, Norway.

[79] Sen, A. K. (1991) Poverty and Famines; An Essay on Entitlement and Deprivation. Clarendon Oxford Press.

[80] Strauss, J. F. (2003) Macro-economics and Gender: Options for their Integration into a State Agenda. New York and London: Zed Books.

[81] Tuckman, B. W. (1994). Conducting Educational Research. New York: Harcourt Brace College.

[82] UNDP (2015). Sustainable Development Goals, New York: UNDP.

[83] UNDP (2006) Millennium Development Goals Needs Assessment Report. Nairobi: Ministry of Planning and National Development.

[84] UNDP (2005). A Fair Share for Women; Briefing Kit on Gender \&Millennium Development Goals. Nairobi: Association of Media Women in Kenya (AMWIK).

[85] UNDP (2004). Human Development Report. New York: Oxford University press.

[86] UNDP (2003a). Poverty Reduction and Human Rights. New York: UNDP.

[87] UNDP (2003b). Report from the Inter-Agency workshop on implementing a Human Rights- based approach in the context. Stamford. UNDP.

[88] UNDP (1997). Human Development Report. New York: Oxford University Press.

[89] Van Cott, D. L (2000) The Friendly Liquidation of the Past: The Politics of Diversity in Latin America, Pittsburg: University of Pittsburg.

[90] Waller, R. D (1993b) Being Maasai; Ethnicity and Identity in East Africa. London: James Currey.

[91] Webster, M. (1985). New Collegiate Dictionary. Meriam: Webster Inc.

[92] Wellington, J. J. (1996). Methods and Issues in Educational Research. Shieffield: University of Sheielfield, Division of Education.

[93] World Bank (2015). Improving Delivery in Development; The role of Voice, Social Contract and Accountability. The World Bank Legal Review Vol.6, International Bank for Reconstruction and Development. Washington DC.

[94] World Bank (2002) A World Bank Policy Research Report; Engendering Development Through Gender Equality in Rights, Resources, and Voice. New York. Oxford University Press.

[95] Zinkmund, W. (1998). Business Research Methods. New York: Dryden Press. 